\title{
Operasi Hitung Sederhana dengan Media Tangga Pintar Anak Tunagrahita
}

\author{
Nurul Khikmah Maulidiyah, Sudarsini, Asep Sunandar \\ Universitas Negeri Malang \\ e-mail : nurulmaulidiyah31@gmail.com
}

\begin{abstract}
Abstrak : Peningkatan kemampuan operasi hitung sederhana dengan media tangga pintar bagi anak tunagrahita. Tujuan dari penelitian ini adalah untuk mendeskripsikan pengaruh media tangga pintar pada kemampuan operasi hitung berhitung 1 sampai 10 siswa tunagrahita. Metode yang digunakan adalah eksperimen dengan menggunakan one group pre-test post-test. Data dianalisis dengan menggunakan uji Wilcoxon. Hasil penelitian menunjukkan bahwa media tangga pintar berpengaruh terhadap kemampuan operasi hitung sederhana siswa tunagrahita.
\end{abstract}

Kata Kunci : Tunagrahita, media tangga pintar, operasi hitung sederhana

\begin{abstract}
Enhancing the ability of simple counting operations with smart ladder media for mentally retarded children. This study aims to describe the effect of smart ladder media on the ability to count 1 to 10 mentally retarded students. The method used is an experiment using one group pre-test post-test. Data were analyzed using the Wilcoxon test. The results showed that smart ladder media had an effect on simple arithmetic operations of mentally retarded students.

Keyword : Mentally retardation, smart ladder media, simple counting operations
\end{abstract}

Pada proses belajar mengajar, hal yang terpenting untuk mencapai tujuan pembelajaran tersebut adalah peran aktif siswa dalam pelaksanaan pembelajaran di kelas. Hal tersebut sangat berpengaruh dalam pencapaian tujuan pembelajaran yang diinginkan. Artinya proses belajar harus menghasilkan perubahan. Perbedaan anak berkebutuhan khusus dengan anak regular bisa dilihat dari segi fisik, mental, emosi, dan sosial. Maka dari itu dibutuhkan pembelajaran khusus untuk memenuhi kebutuhan pendidikan mereka. Seringkali sulit membedakan antara anak tunagrahita ringan dengan anak normal karena kondisi fisik anak tunagrahita ringan sama dengan kondisi fisik pada anak normal. Biasanya gejala pada anak tunagrahita ringan isa diketahui pada saat usia sekolah tingkat dasar dan dituntut untuk menguasai sebuah pembelajaran yang semakin sulit. Secara akademik mereka tidak mampu untuk mengikuti alur pembelajaran dengan baik. Seperti yang dikemukakan Effendi (2017) pemilikan pemahaman oleh pendidik anak berkebutuhan khusus terhadap berbagai hal yang berkenaan dengan keberadaan anak tunagrahita kelak diharapkan dapat memiliki konsep yang benar tentang pendidikan anak tunagrahita serta mengaplikasikan dalam pemberian layanan pendidikan yang relevan kebutuhan anak tunagrahita. Selama ini perkembangan ilmu pengetahuan dan teknologi yang berkembang pesat tidak terlepas dari peran besar matematika. Matematika merupakan ilmu yang mempelajari tentang logika. Sulit sekali bagi anak tunagrahita untuk diajarkan cara berfikir yang abstrak dan konseptual.. Menurut Moh. Amin (1995), meskipun siswa tunagrahita ringan kesulitan untuk berfikir secara abstrak, namun mereka masih bisa mengikuti pelajaran akademik di sekolah regular atau di sekolah khusus. Cara mengajar berhitung untuk tunagrahita memadukan dua aspek yaitu aspek matematis dan aspek sosial agar dapat diserap oleh anak. Jika anak tunagrahita hanya diberi aspek matematis saja anak akan kebingungan dan sulit memahami. Anak tunagrahita juga akan cepat melupakan pembelajaran tersebut. Hal tersebut dikarenakan oleh kemampuan yang terbatas dan daya ingat anak tunagrahita yang lemah. Menurut Sundayana (2013) mengemukakan bahwa, hampir semua orang menganggap tingkat kesulitan pelajaran matematika sangatlah tinggi, tetapi setiap orang harus mempelajari matematika karena merupakan sarana untuk memecahkan masalah pada kehidupan sehari - hari. Maka dari itu untuk mempermudah siswa tunagrahita mempelajari operasi hitung bisa menggunakan media. Menurut Kustiawan (2013) definisi dari media pembelajaran merupakan suatu hal berupa benda yang digunakan guru untuk menyampaikan materi pelajaran kepada siswa, sehingga dapat menarik minat dan perhatian siswa sehingga merangsang pikiran dan perasaan pada kegiatan pembelajaran dalam rangka mencapai tujuan belajar. Penggunaan media pembelajaran bisa digunakan sebagai alat bantu untuk mempermudah siswa dalam pemahaman materi operasi hitung sederhana dalam pembelajaran matematika.

Hasil studi pendahuluan di SDLB Idayu 2 Pakis Kabupaten Malang, ditemukan 7 siswa pada kelas II tunagrahita yang kemampuannya sangat kurang dalam operasi hitung sederhana. Mereka kesulitan dalam penjumlahan dan pengurangan, karena mereka sering merasakan jenuh pada saat pelajaran matematika. Guru hanya menjelaskan penjumlahan dan pengurangan dengan media seadanya jadi siswa merasa kurang tertarik dan mudah bosan. Tidak jarang siswa malah 
mengabaikan apa yang sudah dijelaskan oleh guru.

Berdasarhan penjelasan diatas, penulis tertarik untuk mengambil judul "Pengaruh Media Tangga Pintar Untuk Meningkatkan Kemampuan Operasi Hitung Sederhana Pada Siswa Tunagrahita Kelas 2 Di SDLB Idayu 2 Pakis"

\section{METODE}

Dalam rancangan penelitian yang akan diberikan, rancangan Pre-Experimental design yang digunakan oleh peneliti. Menurut Sugiyono (2015) karena masih ada pengaruh dari variabel luar terhadap terbentuknya variabel dependen maka dari itu dikatakan pre experimental design.. Hal ini bisa terjadi, karena tidak ada variabel kontrol dan sampel tidak dipilih secara acak. Ada beberapa macam bentuk dalam design preexperimental. Disini penulis menggunakan desaign preexperimental bentuk one-group pretetst-posttest design. Pada design ini melewati 3 tahap yang pertama pretes, treatmen, dan yang terakhir pos-tes. Ada pengaruh atau tidak penggunaan media untuk kemampuan operasi hitung sederhana siswa bisa diketahui dengan cara mengukur kemampuan berhitung siswa sebelum ada perlakuan dan setelah adanya perlakuan sehingga tidak diperlukan kelompok kontrol. Pretest dilaksanakan 1 kali, kemudian perlakuan dilakukan empat kali pertemuan dan post test dilaksanakan 1 kali.

\section{HASIL DAN PEMBAHASAN}

\section{Hasil}

Berdasarkan tabel diatas dapat diketahui kemampuan operasi hitung sederhana sebelum menggunakan media tangga pintar memperoleh skor rata-rata sebesar 58,6. Artinya kemampuan berhitung peserta didik sebelum diberikan media tangga pintar masih dalam kategori kurang.

Dapat dilihat dari keterangan pada tabel bisa diketahui kemampuan operasi hitung sederhana pada siswa sesudah penggunaan media tangga pintar memperoleh skor rata-rata sebesar 80 .

Berdasarkan tabel dan diagram diatas, dari data 7 peserta didik secara keseluruhan mengalami peningkatan kemampuan berhitung. Peningkatan kemampuan operasi hitung sederhana ini bisa dilihat dari hasil skor rata-rata yang didapat setelah melaksanakan post-test (80) lebih besar atau lebih tinggi dari nilai rata-rata setelah pre-test $(58,6)$.

Untuk menguji hipotesis penelitian digunakan Uji Wilcoxon diawali dengan menentukan skor $T_{\text {hitun }}$ dengan bantuan tabel perhitungan Wilcoxon sebagai berikut:
Tabel 1. Kemampuan operasi hitung sederhana siswa tunagrahita sebelum mendapatkan perlakuan atau treatment

\begin{tabular}{|c|c|c|}
\hline No. & Nama & Nilai \\
\hline 1. & DN & 80 \\
\hline 2. & ZD & 50 \\
\hline 3. & LV & 40 \\
\hline 4. & SV & 70 \\
\hline 5. & GL & 50 \\
\hline 6. & JS & 60 \\
\hline 7. & NY & 60 \\
\hline \multicolumn{2}{|c|}{ Jumlah } & 410 \\
\hline \multicolumn{2}{|c|}{ Rata-rata } & 58,6 \\
\hline
\end{tabular}

Tabel 2. Kemampuan operasi hitung sederhana siswa tunagrahita setelah mendapatkan perlakuan atau traetment (Post-test)

\begin{tabular}{lll}
\hline No. & Nama & Nilai \\
\hline 1. & DN & 100 \\
2. & ZD & 70 \\
3. & LV & 50 \\
4. & SV & 100 \\
5. & GL & 80 \\
6. & JS & 70 \\
7. & NY & 90 \\
\hline Jumlah & 560 \\
\hline \multicolumn{2}{l}{ Rata-rata } & 80 \\
\hline
\end{tabular}

Tabel 3 . Pengaruh Media Tangga Pintar Untuk Meningkatkan Kemampuan Operasi Hitung Sederhana Pada Siswa Tunagrahita Kelas II di SDLB Idayu 2 Pakis

\begin{tabular}{lllll}
\hline No. & Nama & Pre-test & Post-test & Keterangan \\
\hline 1. & DN & 80 & 100 & Meningkat \\
2. & ZD & 50 & 70 & Meningkat \\
3. & LV & 40 & 50 & Meningkat \\
4. & SV & 70 & 100 & Meningkat \\
5. & GL & 50 & 80 & Meningkat \\
6. & JS & 60 & 70 & Meningkat \\
7. & NY & 60 & 90 & Meningkat \\
\hline Jumlah & $\mathbf{4 1 0}$ & $\mathbf{5 6 0}$ & Meningkat \\
\hline Rata-rata & $\mathbf{5 8 , 6}$ & $\mathbf{8 0}$ & Meningkat \\
\hline
\end{tabular}

Menurut perhitungan uji Wilcoxon, yang bisa dilihat pada keterangan tabel skor tertinggi 100 dan skor terendah 50. Nilai pre-test dan post-test semua siswa tidak ada yang mendapat perhitungan dengan 
selisih negatif (-),jadi semua siswa memperoleh tanda positif $(+)$. Kemudian ranking yang bertanda positif dan bertanda negatif dijumlahkan, lalu yang memperoleh hasil terkecil dijadikan Thitung $=0$, yaitu paling kecil jumlah harga mutlaknya. Nilai kritis untuk uji Wilcoxon $\alpha=0,05$ dan $n=7$ (jumlah sampel) dari daftar uji Wilcoxon diperoleh Ttabel $=2$. Berdasarkan perhitungan yang dilakukan dengan uji Wilcoxon dengan $\mathrm{n}=7$ pada taraf signifikan $\alpha=0,05$ diperoleh Ttabel $=2$, maka $\mathrm{H} 0$ ditolak karena Thitung (0) < Ttabel (2), hal tersebut memiliki arti bahwa hipotesis yang diajukan telah diterima. Hal tersebut menunjukkan bahwa media tangga pintar berpengaruh terhadap kemampuan operasi hitung permulaan siswa Tunagrahita kelas II di SLB Idayu 2 Pakis Kabupaten Malang.

\section{Pembahasan}

Kemampuan Operasi Hitung Sederhana pada Anak Tunagrahita sebelum diberikan treatment menggunkan media Tangga Pintar

Kondisi awal sebelum diberikan treatment menunjukkan kemampuan berhitung pada anak tunagrahita termasuk dalam kategori rendah. Hal tersebut diketahui dari hasil analisis yang dilakukan melalui tahap pre-test sebelum diadakannya atau dilakukan treatment terhadap siswa. Menurut Effendi (2017) yang menjadi dasar dalam pengembangan pembelajaran untuk peserta didik berkebutuhan khusus yaitu kasih sayang, kesiapan, layanan individual, motivasi, belajar untuk bekerja kelompok, ketrampilan, dan juga penanaman untuk penyempurnaan sikap. Salah satu dari dasar pengembangan pembelajaran tersebut adalah keperagaan. Keperagaan tersebut sangat mendukung terhadap pembelajaran pada anak berkebutuhan khusus, yaitu siswa dengan mudah akan memahami materi yang disampaikan oleh guru. Jadi keperagaan seperti media sangatlah mendukung untuk menunjang proses pembelajaran siswa. Supaya siswa juga lebih tertarik dan ikut aktif dalam pembelajaran.

Sriningsih (2008), berpendapat tujuan dari berhitung adalah untuk perkembangan anak dalam pemahaman dengan proses eksplorasi menggunakan benda - benda nyata. Dalam penelitian yang dilakukan siswa memiliki pemahaman dalam berhitung sangat kurang, siswa juga kesulitan untuk menjumlahkan dan mengurangkan angka yang ada disoal. Dari ketujuh siswa beberapa diantaranya terdapat siswa yang harus mendapat perhatian dan bimbingan dari guru secara intensif jika guru sedang menangani subjek lain siswa akan diam tidak mengerjakan soal yang diberikan. Sehingga peneliti harus melakukan pembelajaran secara klasikal dilanjutkan dengan pembelajaran secara individual.

Sama halnya yang sudah dikatakan pada saat kondisi awal sebelum diberikan treatment, siswa mengalami kesulitan dalam hal berhitung karena kurangnya media dan konsentrasi belajar. Pada saat diberikan pre-test sebelum siswa menerima treatment menggunakan media tangga pintar, nilai rata-rata yang diperoleh siswa tunagrahita kelas II SDLB tergolong sangat rendah dengan jumlah subjek 7 yaitu 58,6.

Kemampuan Operasi Hitung Sederhana Anak Tunagrahita setelah diberikan treatment menggunakan media Tangga Pintar

Pada saat sudah diberi treatment, kemampuan siswa tunagrahita kelas II SDLB Idayu 2 Pakis dalam melakukan operasi hitung sederhana mengalami kemajuan atau peningkatan. Bisa dikatakan demikian karena dilihat berdasarkan perolehan nilai siswa setelah diberikan treatmen dan sebelum diberikan treatmen. Setelah diberi treatmen nilai siswa bisa dikatakan sangat meningkat. Pada saat pemberian treatmen sangat terlihat siswa begitu antusisa dan bersemangat saat belajar berhitung menggunakan media tangga pintar. Pembelajaran atau treatment yang diberikan secara individual dan memberikan tugas kepada siswa yang lain, dalam pembelajaran ini guru juga membantu siswa dalam menyelesaikan latihan soal. Hal ini sejalan dengan penelitian yang dilakukan oleh Wahyuningtyas (2015) penggunaan media dapat mempengaruhi ketangkasan anak dalam mengerjakan soal. Adanya media sangat membantu anak dalam mengerjakan soal operasi hitung pada pelajaran matematika.

Kesimpulan dari pernyataan diatas adalah media tangga pintar berpengaruh terhadap hasil kemampuan operasi hitung sederhana pada siswa tunagrahita kelas II di SDLB Idayu 2 Pakis Kabupaten Malang analisis hasil belajar (post-test) menbuktikan dengan rincian hasil dari 7 orang subjek dengan nilai sebagai berikut 100, 70, 50, 100, 80, 70, 90 dibandingkan dengan nilai pada saat pre-test yaitu $80,50,40,70,50,60,60$.

Pengaruh Media Tangga Pintar terhadap Kemampuan Operasi Hitung Sederhana pada Anak Tunagrahita

Berdasarkan hasil uji hipotesis, ada pengaruh dari media tangga pintar terhadap kemampuan operasi hitung sederhana siswa tunagrahita kelas II SLB Idayu 2 Pakis Kabupaten Malang. Dilihat dari tabel nilai tes tulis dapat diketahui dari nilai rata-rata pre-test adalah 58,6 dan nilai rata-rata post-test adalah 80. Dengan membandingkan hasil rata-rata pada nilai siswa saat menjawab soal tes tulis, ketika sebelum dan setelah diberikan perlakuan maka terlihat peningkatan nilai yang signifikan. Dengan uji Wilcoxon dengan $n=7$ pada taraf signifikan 0,05 diperoleh nilai $\mathbf{T}_{\text {hitung }}=\mathbf{0}$ dan $\mathbf{T}_{\text {tabel }}=\mathbf{2}$, maka $\mathbf{H}_{\mathbf{0}}$ ditolak karena $\mathbf{T}_{\text {hitung }}(0)<\mathbf{T}_{\text {tabel }}(2)$ yang memiliki arti bahwa hipotesis yang telah diajukan diterima. Hal ini menunjukkan kegiatan berhitung menggunakan medi tangga pintar berpengaruh terhadap peningkatan kemampuan operasi hitung 
sederhana siswa tunagrahita kelas II di SDLB idayu 2 Pakis.

Pada skripsi Vera (2018) menjelaskan "berdasarkan hasil penelitian tangga pintar ini layak digunakan sebagai media pembelajaran karena dapat mempengaruhi peningkatan kemampuan siswa di bidang matematika operasi hitung sederhana pada siswa kelas I di SD Muhammadiyah Mantaran"

Secara umum kemampuan berhitung sederhana menunjukkan kanaikan hasil saat diberikan pre-test dan post-test. Kemampuan operasi hitung sederhana sebenarnya bisa diberikan kepada siswa tunagrahita dengan cara diulang - ulang. Hal tersebut berkaitan dengan salah satu karakteristik anak tunagrahita adalah model pembelajarannnya harus berulang-ulang, akan tetapi jika tidak disertai media yang bersifat nyata maka pembelajaran tersebut tidak akan efektif. Pada penelitian ini tangga pintar dipilih sebagai media pembelajaran operasi hitung sederhana bertujuan memudahkan siswa tunagrahita kelas II dalam memahami operasi hitung sederhana penjumlahan dan pengurangan dengan cara yang menyenangkan.

\section{KESIMPULAN DAN SARAN}

\section{Kesimpulan}

Hasil kesimpulan secara keseluruhan menunjukkan bahwa media tangga pintar bisa meningkatkan kemampuan operasi hitung sederhana anak tunagrahita kelas II. Peningkatan ini dapat ditunjukkan dari hasil pre-test dengan rata-rata 58,6 meningkat degan hasil post-test 80 . Ada berbedaan yang signifikan antara kemampuan operasi hitung sederhana sebelum diberikan treatmen dan sesudah diberikan treatmen menggunakan media tangga pintar, dengan kata lain ada pengaruh media tangga pintar terhadap kemampuan operasi hitung siswa tunagrahita kelas II di SLB Idayu 2 Pakis Kabupaten Malang.

\section{Saran}

Dari hasil penelitian di lapangan, guru diharapkan bisa lebih mengoptimalkan kemampuan pada anak Tunagrahita dengan menggunakan indra lain yang masih bisa digunakan. Dengan cara bisa dengan memberikan media atau metode pembelajaran yang kreatif bisa digunakan sebagai fasilitas dalam pembelajaran. Media tangga pintar dalam pembelajaran Matematika dapat diterapkan untuk membantu siswa dalam meningkatkan kemampuan operasi hitung sederhana. Dan untuk peneliti selanjutnya diharapkan bisa mengembangkan peneletian yang menggunakan media tangga pintar pada anak yang memiliki karakteristik berbeda sehingga dapat digunakan untuk melatih siswa meningkatkan kemampuan operasi hitung sederhana.

\section{DAFTAR PUSTAKA}

Amin, M. (1995). Ortopedagogik Anak Tunagrahita. Depdikbud, Dirjen, Dikti, Jakarta

Efendi, M. (2017). Psikopedagogik Anak Berkebutuhan Khusus. Malang: Universitas Negeri Malang

Kustiawan, U. (2013). Sumber dan Media Pembelajaran Anak Usia Dini. Malang: UM

Sugiyono. (2015). Metode Penelitian Pendidikan Pendekatan Kuantitatif, Kualitatif, dan R\&D. Bandung: Alfabeta

Sundayana, (2014). Media dan Alat Peraga dalam Pembelajaran Matematika. Bandung: CV Alfabeta

Vera, Y. (2018) Pengembangan Media Pembelajaran Tangga Pintar Materi Penjumlahan dan Pengurangan Kelas I Sekolah Dasar. Artikel (Online),

Wahyuningtyas ,D. (2015). Penggunaan Media Mobil Mainan Untuk Meningkatkan Pemahaman Konsep Operasi Hitung Bilangan Bula.Jurnal(Online),

Wahyuningtyas, P.A. (2015). Peningkatan Kemampuan Mengenal Huruf Melalui Media Papan Flanel Pada Anak Usia Dini Di Tempat Penitipan Anak Beringharjo Yogyakarta. Jurnal Elektronik Mahasiswa Pend. Luar Sekolah-S1, 4(3). 